\title{
敗血症ガイドライン
}

西江宏行

岡山大学病院 麻酔科蘇生科

\section{Guidelines for management of severe sepsis and septic shock}

Hiroyuki Nishie

Department of Anesthesiology and Resuscitology, Okayama University Hospital

\section{はじめに}

2013年 2 月に Critical Care Medicine 誌で「Surviving Sepsis Campain : International Guideline for Management of Severe Sepsis and Septic Shock : 2012 $\rfloor^{1)}$ (以下 SSCG) が，2013年 4 月に日本集中治療医学 会誌で「日本版敗血症診療ガイドラ イン」2) が発表された(以下日本版). 両者は近い時期に発表されている が，若干内容が異なる部分もある。 この二つのガイドラインの概要を述 ベる.両者とも膨大な量となるため, 多少省いての記載とした。詳しくは 論文を参照されたい。

\section{推奨のグレード (SSCG)}

SSCG では GRADE (grading of recommendations assessment, development and evaluation) system が用いられ,エビデンスの質は A (高 い), B (中間), C (低い), D (と ても低い) に分けられている。推奨 度は 1 (強い), 2 (弱い) に分けら れている。なお, 小児についての推 奨, 分類なし (UG) についてはこの 紙面上では割愛した。

（）はSSCG，[]は日本版での GRADEである。

平成 25 年 5 月受理 干700-8558 岡山市北区鹿田町 2-5-1 電話：086-235-7327

FAX : 086-235-7329

E-mail : nishiehiroyuki@gmail.com
SSCG では以下の七つがバンドル として記載され，すべて行うことが 推奨されている.

3 時間以内に完了されるものとし て(1)乳酸值の測定，(2)抗生剂投与前 に血液培養を行う，(3)広域抗生剂を 投与，(4)低血圧もしくは乳酸值 $\geq 4$ $\mathrm{mmol} / \mathrm{l}$ の時は $30 \mathrm{ml} / \mathrm{kg}$ の晶質液を 投与.

6 時間以内に，5初期輸液負荷に 反応しない低血圧に対しては血管収 縮薬を用いて，平均血圧 $65 \mathrm{mmHg}$ を保 つ，6輸液負荷に反応しない低血圧 もしくは最初の乳酸值がミ4 mmol/1

表 1 敗血症診断のための補助的指標

（注：SSCG との違いは（）で記入）文献 2 より改編

\section{全身的指標}

発熱 [深部温 $>38.0^{\circ} \mathrm{C}$ ] (SSCG : $\left.38.3^{\circ} \mathrm{C}\right)$

低体温 [深部温 $<36.0^{\circ} \mathrm{C}$ ]

心拍数 $[>90 / \mathrm{min}$ または年齢の基準值より> $2 \mathrm{SD}$ ：標準偏差 $]$

頻呼吸 $[>20 / \mathrm{min}]$

精神状態の変化

著明な浮腫または体液増加 [24時間で $>20 \mathrm{ml} / \mathrm{kg}$ ］

高血糖［血糖值 $>120 \mathrm{mg} / \mathrm{dl}$ ただし非糖尿病患者］（SSCG：>140mg/dl）

炎症反応の指標

白血球增多 $[\mathrm{WBC}>12,000 / \mu \mathrm{l}]$

白血球減少 $[\mathrm{WBC}<4,000 / \mu 1]$

白血球数正常で未熟型白血球 $>10 \%$

$\mathrm{CRP}[>2.0 \mathrm{mg} / \mathrm{dl}]$ （基準值より>2SD）

PCT $[>0.5 \mathrm{ng} / \mathrm{dl}$, 重症敗血症 $>2.0 \mathrm{ng} / \mathrm{dl}]$ （基準值より $>2 \mathrm{SD}$ )

IL-6［重症敗血症 $>1,000 \mathrm{pg} / \mathrm{ml} ＼mathrm{~ （ S S C G ~ に は 記 載 な し ） ~}$

循環動態の指標

低血圧 $[$ 成人では収縮期血圧 $<90 \mathrm{~mm} H \mathrm{H}$ もしくは平均血圧 $<70 \mathrm{mmHg}$ 。または収縮期血

圧 $40 \mathrm{~mm} H \mathrm{~g}$ 以上の低下．小児では年齢基準值よりも $2 \mathrm{SD}$ 以上の低下］

臟器障害の指標

低酸素血症 $[\mathrm{PaO} 2 / \mathrm{FiO} 2<300]$

急な尿量減少 $[$ 尿量 $<0.5 \mathrm{ml} / \mathrm{kg} / \mathrm{hr}$ ]

$\mathrm{Cr}$ の上昇 $[>0.5 \mathrm{mg} / \mathrm{dl}]$

凝固異常 [PT-INR $>1.5$ または APTT $>60$ 秒 $]$

イレウス [腸蠕動音の消失]

血小板数減少 $[<100,000 / \mu 1]$

高ビリルビン血症 [T-Bil $>4 \mathrm{mg} / \mathrm{dl}$ ]

臟器灌流の指標

高乳酸血症 $[>2 \mathrm{mmol} / \mathrm{l}](\mathrm{SSCG}:>1 \mathrm{mmol} / \mathrm{l})$

毛細血管再充満時間の延長，またはまだらな皮膚 
のとき, 中心静脈圧, 中心静脈血酸 素飽和度を測定する, (7)初期の乳酸 值が上昇した時は再測定する。

\section{初期蘇生}

敗血症による組織低灌流（初期輸 液負荷後も続く低血圧もしくは, 乳 酸值 $\geq 4 \mathrm{mmol} / \mathrm{l}$ ）の患者に対して, 初期の 6 時間の目標は, 以下のとお りである。

(1) a) 中心静脈圧 $8 \sim 12 \mathrm{mmHg}$, b ) 平均血圧 $\geq 65 \mathrm{mmHg}, \mathrm{c}$ ）尿量 $\geq$ $0.5 \mathrm{ml} / \mathrm{kg} / \mathrm{hr}, \mathrm{d}$ ) 中心静脈（上大 静脈）酸素飽和度70\%，もしくは混 合静脈血酸素飽和度 $65 \%$ （1 C ).

(2)乳酸值の上昇している患者に対 しては正常化を目標とする ( 2 C).

その他, 日本版では観血的動脈圧 測定で血圧を連続的に監視し, 動脈 血ガス分析を時系列で行うこと [1 D], 代謝性アシドーシスの改善と乳 酸クリアランスを少なくとも 6 時間 毎に評価すること [ $1 \mathrm{~A}]$ が推奨さ れる。

\section{診断}

抗生剂治療前に適切に培養する。 （好気性と嫌気性の）少なくとも2 セットを抗生剂治療前に採取する。 少なくとも一つは経皮的に，もう一 つは48時間以上挿入されているもの でなければ血管ルートから採取する ( 1 C). 侵襲性カンジダ症が鑑別疾 患となる場合は, 可能なら $1,3 \beta-\mathrm{D}$ グルカン $(2 \mathrm{~B})$, マンナン抗原, 抗 マンナン抗体（2 C ）を検査する. なお，敗血症の診断のために血液培 養から病原微生物あるいは病原微生 物の毒素が検出される必要はない

[ 1 C ]. 敗血症の診断には CRP,

IL-6, PCT がある程度有用である が，敗血症を確実に診断できるバイ オマーカーはない $[1 \mathrm{C}]$. 血液培養 を提出する際には穿刺部の皮膚をア ルコール含有クロルヘキシジン，ア
ルコール含有 $10 \%$ ポピドンヨード, あるいはアルコール全清拭後水溶性 10\%ポピドンヨードで消毒する [1 C ］. 血液は 1 セットあたり $20 \mathrm{ml}$ を 2 セット以上採取する $[1 \mathrm{C}]$ 。

\section{抗菌療法}

敗血症性ショック（1 B ）あるい は, 敗血性ショックのない重症敗血 症（1 C ）の診断から 1 時間以内に 抗生剂を静脈内投与する。最初は考 えうる病原体 (細菌, 真菌, ウイル ス）に対して，一つもしくはそれ以 上の薬剤を用いて経験的治療を行 う。そして, 感染源と考えられる組 織に適切な濃度で浸透するようにす る $(1 \mathrm{~B})$. 抗生剤投与計画は, デエ スカレーション（注：より狭いスペ クトル抗生剤への変更) の可能性を 考えて毎日見直す (1 B ). 経験的抗 生剂治療は $3 \sim 5$ 日を超えない.デ エスカレーションは, 結果がわかっ たらすぐに行うべきである ( 2 B ). 治療は一般的に $7 \sim 10$ 日である。た た，臨床的な反応が遅い場合，感染 源が取り除けない, 黄色ブドウ球菌, ある種の真菌，ウイルス感染や白血 球減少を含む免疫抑制患者ではより 長いほうが良いかもしれない $(2 \mathrm{C})$. ウイルスが原因の重症敗血症や敗血 症性ショックの患者にはできるだけ 早く抗ウイルス治療を始める $(2 \mathrm{C})$. 経験的治療では, 原因感染症を推定 し, その感染症で疫学的に頻度の高 い病原菌を十分にカバーできる広域 抗菌剤の投与を行う $[1 \mathrm{C}]$. 原因菌 が確定したら, 感受性結果を評価し, 抗菌薬を標的治療薬に変更する $[1$ D].

\section{感染源コントロール}

感染源は，できるだけ早く探し， 診断もしくは排除されるべきであ る。そして，できれば診断から12時 間以内に感染源コントロールのため
にインターベンションを行う（1 C). 感染巣の特定が困難な場合は造 影 CT が推奨される [1 D ].

\section{感染予防}

SSCGでは選択的口腔内除菌 （SOD）や選択的消化管除菌（SDD） が，人工呼吸関連肺炎（VAP）の予 防法として弱く推奨されているが

(2 B ), 日本版では, SDD, SOD は耐性菌保菌者での有効性が不確定 であり, 耐性菌出現率が増加する可 能性があるため積極的には行わない

[2 B ] としている.SSCGでは口 咽頭の除菌としての口腔内グルコン 酸クロルヘキシジンが ICU 内の重 症敗血症患者の VAP の減少に用い られる（2B).

\section{輸液療法と重症敗血症}

重症敗血症と敗血症性ショックに 対する初期輸液としては晶質液を選 択し(1B), hydroxyetyl starch(HES) を用いない（1 B ). 多くの晶質液を 必要とする重症敗血症と敗血症性シ ヨック患者にはアルブミンを用いる ( 2 C). 循環血液量減少が疑われる 敗血症誘発の組織低潅流に対する初 期輸液は最低 $30 \mathrm{ml} / \mathrm{kg}$ の晶質液を用 いる（この一部は相当するアルブミ ンにしてもよい).より速く, 多い輸 液が必要な場合もある（1C)。

\section{血管収縮薬}

血管収縮薬は初期には平均血圧 65 mmHgを目標とし（1Ｃ），ノルアドレ ナリンが第一選択である（1 B ). 適 切な血圧を保つため必要な場合はア ドレナリンを用いる（1Ｂ）。ノルア ドレナリンの代わりにドーパミンを 使うのは特に選択された患者のみに する（1 C). 以下の場合を除いてフ エニレフリンは推奨しない $(1 \mathrm{C})$.

(1)ノルアドレナリンが重篤な不整脈 に関連する場合，(2)心拍出量が多く 
血圧が低い場合, (3)陽性変力薬と血 管収縮薬の混合や少量のバゾプレッ シンによっても平均血圧の目標に届 かない場合.

低用量ドーパミンは腎保護のため に用いられるべきでない $(1 \mathrm{~A})$ 。ノ ルアドレナリンへの反応性が低下し ている場合にはノルアドレナリンに 加えてバゾプレシンの併用を考慮す る $[2 \mathrm{~B}]$.

\section{陽性変力作用薬}

以下の状態であれば， $20 \mu \mathrm{g} / \mathrm{kg} /$ min までのドブタミン投与を考える. あるいは（もし使われているなら） 血管収縮薬も追加する。 (1)心臓流入 圧の上昇もしくは心拍出量の低下, (2)適切な循環血液量や平均血圧が保 たれているにもかかわらず低灌流の 兆候がある（1 C ).

なお，正常值を超えた心係数 (CI) 増加を得るために薬物を使用しない

(1 B ) こととされる.

\section{コルチコステロイド}

成人の敗血症性ショックの患者 で，適切な輸液負荷や血管収縮薬で 循環動態の安定が得られる場合には ハイドロコロコルチゾンの静注は用 いない。もし安定が得られない場合 には,一日200mgのハイドロコロコル チゾン静注を推奨する $(2 \mathrm{C})$. 日本 版ではハイドロコルチゾンで $300 \mathrm{mg} /$ dl以下， 5 日以上の少量 - 長期投与 が推奨される $[1 \mathrm{~A}]$ 。 ショックがな ければ，敗血症の治療にコルチコス テロイドを投与しない（1Ｄ）。八 ドロコロコルチゾンを使う場合は持 続投与にする $(2 \mathrm{D})$. 日本版では八 イドロコルチゾン換算量で $200 \mathrm{mg} /$ day を 4 分割, または100mgボーラス 投与後に $10 \mathrm{mg} / \mathrm{h}$ の持続投与を行う [2 B]. また, 副作用の記載もあ $り$, 高 $\mathrm{Na}$ 血症, 高血糖, 新たな敗 血症などの発生率が有意に高いこと
[2 B］を指摘している.

\section{輸血製剤の投与}

いったん低灌流が改善して，心筋 虚血, 重症低酸素, 急性出血, 虚血 性心疾患などがなければ，赤血球輸 血は $\mathrm{Hb}<7.0 \mathrm{~g} / \mathrm{dl}$ 以下の時のみ推 奨する.目標は成人で $7.0 \sim 9.0 \mathrm{~g} / \mathrm{dl}$ とする (1 B ). 重症敗血症による貧 血の治療としてエリスロポエチンは 用いない（1Ｂ）。アンチトロンビン は重症敗血症や敗血症性ショックの 治療に用いない（1B）としている が, 日本版では敗血症性 DIC の治療 としてアンチトロンビン単独投与を 弱く推奨している. 重症敗血症の患 者では, 血小板数が $10,000 / \mathrm{mm}^{2}$ 以下の ときに明らかな出血がなくとも血小 板を予防投与する. 出血の危険性が ある患者では $20,000 / \mathrm{mm}^{2}$ 以下のとき に投与する. 明らかな出血, 手術, 侵襲的手技の際には, $50,000 / \mathrm{mm}^{2}$ 以上 を推奨する（2D).

\section{免疫グロブリン製剤}

SSCG は免疫グロブリン製剤の静 注は成人の重症敗血症や敗血症性シ ヨックの治療に用いない（2 B ）と した。しかし日本版では免疫グロブ リン投与による予後改善効果は根拠 が不十分である [2 B ] が，人工呼 吸期間の短縮や ICU 生存率の改善 を認めるため, 免疫グロブリンの投 与を考慮しても良い［2C］として いる.投与時期は敗血症発症早期 $[2$ C）としており，欧米のガイドライ ンとの違いを見せている.

\section{急性呼吸窮迫症候群（ARDS）に対 する人工呼吸}

敗血症誘発性のARDSに対して は一回換気量の目標を $6 \mathrm{ml} / \mathrm{kg}$ とす る ( $1 \mathrm{~A}$, 対 $12 \mathrm{ml} / \mathrm{kg}$ の時).

SSCG ではプラトー圧を測定し, 初期の上限目標は $\leqq 30 \mathrm{cmH}_{2} \mathrm{O}$ とす
る（1 B）としているが，日本版で はプラトー圧が高くなるほど予後が 悪化するが，至適值を設定すること は困難で［2 B ］あるとした。呼気 終末の無気肺を予防するために positive end expiratory pressure

(PEEP) を用いる（1 B ）. SSCG では敗血症による重症 ARDSには 高 PEEP を用いる（2C）としてい るが日本版では, 画一的な至適 PEEP 值の設定は困難［1 B ］とした。敗 血症による重症低酸素患者にはリク ルートメント手技を用いる $(2 \mathrm{C})$.

$\mathrm{PaO} 2 / \mathrm{FiO} 2 \leqq 100$ 以下の敗血症によ る ARDS 患者には経験のある施設 であればうつ伏せの体位を用いる (2 B). 日本版でも同様に弱い推奨 であるが，合併症に留意すべきとし ている $[2 \mathrm{C}]$. 人工呼吸中の敗血症 患者は，誤嚥の危険性を低下させる ため, VAPの予防のために頭を30〜 45度挙上する ( 1 B ).

非侵襲マスク換気が敗血症による ARDS の少数の患者に用いられる

( $2 \mathrm{~B})$. (人工呼吸器の) 適切なウ イーニングプロトコールがあり，重 症敗血症の人工呼吸患者は，次の基 準を満たすときに人工呼吸離脱を目 的として，自発呼吸テストを行う。 (1)覚醒している，(2)循環動態が安定 している（血管収縮薬なし）, (3)新た な重症になりうる問題がない, (4)呼 吸器や PEEP 圧が低い, (5)酸素マス クや鼻カニューラによる酸素投与で 安全である吸気酸素濃度。自発呼吸 テストが成功したら抜管を考えるべ きである $(1 \mathrm{~A})$ ）敗血症による ARDS 患者に対して日常的に肺動 脈カテーテルを用いない（1 A)。低 潅流がなく, 敗血症による ARDS が 確実な患者に対して輸液量は控え目 にする $(1 \mathrm{C})$.気管支痤攣のような 特別な適応がなければ， $\beta 2$ 作動薬 は敗血症によるARDSの治療には 用いない (1 B). 


\section{敗血症に対する鎮静, 鎮痛, 筋弛緩薬}

敗血症の人工呼吸患者には持続あ るいは間欠的な鎮静は最低限にする (1 B ).ARDS でない敗血症患者に は，できれば筋弛緩薬は避ける。も し筋弛緩薬が必要であれば, train of four（TOF）を用いて筋弛緩の強さ を測定してボーラスもしくは持続投 与にする $(1 \mathrm{C})$.

\section{血糖コントロール}

2 回の連続した血糖值測定で 180 $\mathrm{mg} / \mathrm{dl}$ を超えた時に, ICU内の重症 敗血症患者にプロトコール化された 血糖管理を開始する。このプロトコ ールでは目標を $110 \mathrm{mg} / \mathrm{dl}$ 以下にする よりも，180mg/dl以下にすべきであ る（1 A ）。日本版では144～180mg/ dlを目標としている。血糖值測定は, 血糖值とインスリン量が安定するま では $1 \sim 2$ 時間ごとに測定する。そ の後は 4 時間ごとの測定にする（1 C). 毛細管血を使用した簡易血糖測 定法は測定誤差が大きく, 正確性に 欠けるため推奨しない $[1 \mathrm{~B}]$. 敗血 症患者では動脈血静脈血を用いた簡 易測定法, あるいは血液ガス分析器 による迅速血糖測定を用いる。その 際，適宜中央検査室での血糖測定を 行い, その正確性を確認する $[1 \mathrm{~B}]$.

\section{腎代替療法 (renal replacement therapy : RRT)}

持続 RRT と間欠透析は重症敗血 症と急性腎不全の患者には同等の効 果である $(2 \mathrm{~B})$. 循環が安定しない 患者には輸液管理を容易にするため 持続療法を用いる $(2 \mathrm{D})$. 血中尿素 窒素, クレアチニンなど腎機能を指 標としたRRTの開始時期に明確な 基準はない $[2 \mathrm{C}]$. 初期蘇生を行っ ても尿量が得られない重症敗血症, 敗血症性ショックでは早期開始を考 慮しても良い $[1 \mathrm{C}]$. 予後と浄化量
に関するエビデンスレベルの高い RCT は複数存在するが, 至適浄化量 を見出すには至っていない [1 A]. サイトカインなどのメデイエータ除 去を行うには吸着特性を有する膜の 選択，大孔径膜の選択，あるいは血 液浄化量を増やすなどの方法が必要 である $[2 \mathrm{C}]$ 。 上記方法により循環 動態の改善を図ることができる可能 性がある [2 C ].

しかし生命予後を改善するという エビデンスはない $[2 \mathrm{C}]$.日本では 腎不全以外の目的，例えば，サイト カイン除去を目的としてRRTを施 行する場合もあり，このような記述 が追加されているものと考える.

腹部緊急手術を要する敗血症性シ ヨックに対しては, 循環動態改善効 果, 呼吸機能改善効果が示されてい る [2C]. 予後を改善するかどうか については根拠が不十分である [2 $\mathrm{C}]$.

\section{重炭酸療法}

低潅流による乳酸アシドーシスで $\mathrm{PH} \geqq 7.15$ の患者には循環動態の改 善と血管収縮薬の減量を目的として 重炭酸ナトリウムを用いない (2 B).

\section{深部静脈血栓予防}

重症敗血症患者には深部静脈血栓 症の予防薬剂を毎日投与すべきであ る $(1 \mathrm{~B})$.これは, 毎日の低分子へ パリンの皮下投与で行う（1 B， 2 C).クレアチニンクリアランスが $<30 \mathrm{ml} / \mathrm{min}$ のときはダルテパリン （1A）腎代謝の少ない低分子へ パリン（2C）か, 未分画ヘパリン （1 A）を用いる。重症敗血症の患 者には，可能であれば薬物と間欠的 加圧器の組み合わせを用いる $(2 \mathrm{C})$. ヘパリンが禁忌の患者（例：血小板 減少, 重症凝固異常, 活動性出血, 最近の頭蓋内出血）では予防的薬剤 を投与しない（1 B ). 禁忌でなけれ
ば弾性ストッキングか間欠的加圧器 を用いる $(2 \mathrm{C})$. リスクの減少後 は，予防的薬剂を開始する $(2 \mathrm{C})$.

\section{ストレス潰瘍予防}

出血の危険因子を持つ重症敗血 症, 敗血症性ショック患者にはス卜 レス潰瘍予防に H 2 ブロッカーかプ ロトンポンプ阻害薬 (PPI) を用いる (1B)。ストレス潰瘍予防には，H2 ブロッカーよりも PPI を用いる（2 D).リスク因子のない患者には予防 投与しない（2B).

\section{栄養}

重症敗血症/敗血症性ショックの 診断から48時間以内に，経口か経管 栄養を可能な範囲で行う $(2 \mathrm{C})$. 日 本版では入室から 24 時間以内となっ ている $[1 \mathrm{~B}]$. 最初の一週間でカロ リー最大投与するよりむしろ，少な い量の栄養を推奨する（2B). 重症 敗血症/敗血症性ショックの診断か ら 7 日以内に, 完全経静脈栄養や静 脈栄養と経管栄養の併用よりも，グ ルコース静脈投与と経管栄養を行う (2B). 日本版では敗血症発症後 7 日間は経腸栄養によるカロリー投与 を中心に行い，目標総投与カロリー を達成するための積極的な補足的静 脈栄養を行わない $[1$ B $]$ としてい る.免疫調整されているものよりも, されていない栄養を用いる $(2 \mathrm{C})$. 日本版ではグルタミンに関しては十 分なデータなし $[2 \mathrm{~B}]$ ，アルギニン は推奨しない [2 B], EPA, DHA, $\gamma^{リ}$ リレン酸, 抗酸化物質を強化し た栄養剤の使用を考慮してもよい [2 B]．循環作動薬が使用されてい ることは早期経腸栄養の禁忌とはな らないが, 結構動態の不安定な患者 では慎重に開始する $[1 \mathrm{C}]$.

\section{ケアの目標設定}

患者や家族と，ケアの目標，予後 
について話し合う（1 B ）。必要に応 じて緩和医療の原則を用いて, 治療 の中にケアの目標や終末期ケアの計 画を取り入れる $(1 \mathrm{~B})$. ケアの目標 を ICU 入室から 72 時間以内に定め る $(2 \mathrm{C})$.

\section{おわりに}

SSCG と日本版敗血症ガイドライ ンについて概説した. SSCGはアッ プデートされてきており, 乳酸值が 強調され, HES や免疫グロブリンを 推奨しないなど新しく変わってきて いる.日本版も同様の部分が多いが,
免疫グロブリン, SOD, SDD, RRT など SSCG と推奨が逆のところもあ る.この違いは今後の研究により, 日本初のエビデンスになりうる分野 なのかもしれない。

SSCG は要点がまとまっており読 みやすく, 日本版敗血症ガイドライ ンは具体的な薬品名や投与量にまで 言及されており実際的である。是非 一読をお勧めする。

\section{文献}

1) Dellinger RP, Levy MM, Rhodes A, Annane D, Gerlach H, Opal SM,
Sevransky JE, Sprung CL, Douglas IS, Jaeschke R, Osborn TM, Nunnally ME, et al. : Surviving sepsis campaign: international guidelines for management of severe sepsis and septic shock : 2012. Crit Care Med (2013) 41, 580-637.

2 ) 織田成人, 相引黄幸, 池田寿明, 今泉 均, 遠藤重厚, 落合亮一, 小谷穣治, 志馬伸朗, 西田 修, 野口隆之, 松田 直之, 平澤博之, 他：日本版敗血症診 療ガイドライン.日集中医誌 (2013) 20, 143-170. 